\title{
PENERAPAN MODEL PEMBELAJARAN LANGSUNG (DIRECT INSTRUCTION) DISERTAI DISKUSI DAN MEDIA HYPERCHEM UNTUK MENINGKATKAN AKTIVITAS DAN PRESTASI BELAJAR PADA MATERI IKATAN KIMIA KELAS X 1 SMA ISLAM 1 SURAKARTA TAHUN PELAJARAN 2016/2017
}

\author{
Nur Huda Muttaqin, Sri Yamtinah*, dan Suryadi Budi Utomo \\ Program Studi Pendidikan Kimia FKIP Universitas Sebelas Maret, Surakarta, Indonesia
}

*Keperluan korespondensi, HP. 085725490769, email:jengtina_sp@yahoo.com

\begin{abstract}
ABSTRAK
Penelitian ini bertujuan untuk: (1) meningkatkan aktivitas belajar siswa pada materi ikatan kimia kelas X 1 di SMA Islam 1 Surakarta tahun pelajaran 2016/2017 dengan penerapan model Pembelajaran Langsung (Direct Instruction) disertai diskusi dan (2) meningkatkan prestasi belajar pada materi ikatan kimia kelas X 1 di SMA Islam 1 Surakarta tahun pelajaran 2016/2017 dengan penerapan model Pembelajaran Langsung (Direct Instruction) disertai diskusi. Penelitian ini merupakan penelitian tindakan kelas yang terdiri dari dua siklus, dimana masing-masing siklus meliputi, perencanaan, pelaksanaan, observasi, dan refleksi. Subyek penelitian ini adalah siswa kelas X 1 SMA Islam 1 Surakarta tahun pelajaran 2016/2017. Data yang diperoleh berupa prestasi belajar (aspek kognitif dan aspek afektif) dan aktivitas siswa. Sumber data adalah guru dan siswa. Teknik pengumpulan data adalah dengan tes, angket, observasi, dan wawancara, selanjutnya data dianalisis secara deskriptif kualitatif. Hasil penelitian menunjukkan bahwa, (1) penerapan Model Pembelajaran langsung (Direct Instruction) disertai diskusi dapat meningkatkan aktivitas belajar siswa pada materi ikatan kimia di kelas X 1 SMA Islam 1 Surakarta tahun pelajaran 2016/2017. Aktivitas belajar siswa pada siklus I sebesar $92,59 \%$ dan tidak dilanjutkan pada siklus II. (2) penerapan Model Pembelajaran langsung (Direct Instruction) disertai diskusi dapat meningkatkan prestasi belajar siswa pada materi ikatan kimia di kelas X 1 SMA Islam 1 Surakarta tahun pelajaran 2016/2017. Aspek kognitif siswa pada siklus I sebesar $14,82 \%$ meningkat menjadi $77,78 \%$ pada siklus II. Aspek afektif mencapai $88,88 \%$ pada siklus I dan tidak dilanjutkan pada siklus II.
\end{abstract}

Kata Kunci: Penelitian Tindakan Kelas, Pembelajaran Langsung, Diskusi, Aktivitas Belajar Siswa, Prestasi Belajar

\section{PENDAHULUAN}

Pendidikan adalah suatu proses dalam rangka mempengaruhi peserta didik supaya mampu menyesuaikan diri sebaik mungkin dengan lingkungannya, dan dengan demikian akan menimbulkan perubahan dalam dirinya yang memungkinkannya untuk berfungsi secara optimal dalam kehidupan masyarakat. Pada dasarnya pertumbuhan dan perkembangan peserta didik bergantung pada dua unsur yang saling mempengaruhi, yakni bakat yang dimiliki oleh peserta didik sejak lahir, dan lingkungan yang mempengaruhi hingga bakat itu tumbuh dan berkembang [1].

KTSP merupakan singkatan dari Kurikulum Tingkat Satuan Pendidikan, yang dikembangkan sesuai dengan satuan pendidikan, potensi sekolah atau daerah, karakteristik sekolah atau daerah, sosial budaya masyarakat setempat, dan karakteristik peserta didik. KTSP merupakan upaya untuk menyempurnakan kurikulum agar lebih familiar dengan guru, karena mereka 
banyak dilibatkan diharapkan memiliki tanggungjawab yang memadai [2].

Pelajaran kimia adalah mata pelajaran wajib Sekolah Menengah Atas (SMA). Bagi siswa SMA, khususnya siswa yang baru mengenal mata pelajaran ini, menganggap pelajaran kimia merupakan pelajaran yang sulit sehingga siswa merasa kurang mampu mempelajarinya. Kesulitan siswa dalam mempelajari ilmu kimia dapat bersumber pada kesulitan dalam memahami istilah, kesulitan dengan angka, dan kesulitan dalam menghadapi konsep kimia [3]. Sekolah Menengah Atas (SMA) Islam 1 Surakarta, merupakan salah satu sekolah menengah atas swasta terakreditasi A di kota Surakarta yang menggunakan Kurikulum Tahun 2006 (KTSP). Siswa di SMA Islam 1 Surakarta berasal dari berbagai wilayah dengan kemampuan rata-rata menengah kebawah dan tingkat berfikir yang rendah. Berdasarkan hasil pengamatan di kelas dan wawancara dengan guru mata pelajaran kimia, diketahui bahwa banyak siswa mengalami kesulitan dalam mempelajari kimia. Salah satu materi kimia yang dianggap sulit oleh siswa adalah ikatan kimia. Ikatan kimia adalah materi yang berisikan gambaran abstrak tentang ikatan-ikatan yang terjadi pada senyawa, bentuk-bentuk senyawa hingga sifat-sifat senyawa ion maupun kovalen.

Berdasarkan hasil wawancara pada tanggal 4 April 2016 dengan guru mata pelajaran kimia, kesulitan yang sering dialami siswa dalam mempelajari materi ikatan kimia, adalah kurangnya minat belajar siswa dalam mengikuti pelajaran kimia, siswa kurang aktif selama kegiatan pembelajaran, latar belakang siswa yang kebanyakan berasal dari keluarga yang kurang memperhatikan anaknya dan mempunyai kemampuan rata-rata menengah ke bawah, pada umumnya siswa sulit untuk memahami materi yang bersifat teori dan konsep seperti ikatan kimia. Siswa cenderung menghafal tetapi mudah lupa karena tidak memahami konsep khusunya materi ikatan kimia, sehingga berakibat kurangnya prestasi belajar siswa.

Dalam kegiatan belajar mengajar pelajaran Kimia kelas X di SMA Islam 1 Surakarta, khususnya materi Ikatan Kimia guru masih menggunakan metode ceramah sehingga siswa kurang dilibatkan secara aktif. Berdasarkan beberapa penjelasan di atas, solusi yang dapat dilakukan guru adalah memperbaiki proses pembelajaran dengan menggunakan metode pembelajaran yang tepat. Alternatif pembelajaran yang dapat digunakan adalah model pembelajaran direct instruction yang disertai diskusi. Model pembelajaran ini juga menggunakan metode ceramah, tetapi di dalam model pembelajaran ini memberikan panduan secara bertahap dan terstruktur serta memberikan kemudahan bagi siswa yang tingkat berfikirnya masih rendah untuk secara perlahan dan bertahap diarahkan untuk mengembangkan tingkat berfikir yang lebih tinggi. Jadi model ini sesuai dengan karakter siswa yang mengalami transisi dari penerapan model lama yang menuju penerapan model baru yang menuntut siswa aktif [4].

Media merupakan sarana untuk menuju ke suatu tujuan yang di dalamnya terkandung informasi yang dapat dikomunikasikan kepada siswa. Berdasarkan observasi dan wawancara kepada guru mata pelajaran kimia media yang digunakan ketika proses pembelajaran hanyalah berupa LKS saja. Salah satu contoh media pembelajaran adalah hyperchem. Melalui aplikasi hyperchem dapat membantu siswa dalam memahami konsep abstrak dalam materi ikatan kimia sehingga prestasi belajar siswa meningkat. Penggunaan model pembelajaran Direct Instruction pada mata pelajaran kimia dapat mengurangi miskonsepsi siswa dalam memahami materi yang dijelaskan oleh guru dan memudahkan siswa untuk menerima materi secara tahap demi tahap [5]. Pembelajaran RPL dengan model pembelajaran langsung (Direct Instruction) di Universitas Pendidikan Indonesia berhasil dan efektif dalam 
meningkatkan pemahaman belajar siswa dalam pembelajaran [6]. Model make a match dan metode diskusi dapat meningkatkan prestasi belajar, dibuktikan dengan meningkatnya ketuntasan belajar siswa menjadi $79,41 \%$. Pada proses diskusi berlangsung siswa juga terlihat lebih aktif dalam proses pembelajaran [7].

Berdasarkan uraian tersebut, maka dilakukan penelitian mengenai penerapan model pembelajaran langsung (direct instruction) disertai diskusi dan media hyperchem untuk meningkatkan aktivitas belajar dan prestasi belajar pada materi ikatan kimia kelas X 1 SMA Islam 1 Surakarta Tahun Pelajaran 2016/2017.

\section{METODE PENELITIAN}

Penelitian ini merupakan penelitian tindakan kelas yang terdiri dari dua siklus, dimana masing-masing siklus meliputi, perencanaan, pelaksanaan, observasi, dan refleksi.

Subjek penelitian adalah siswa kelas $X 1$ semester ganjil SMA Islam 1 Surakarta tahun pelajaran 2016/2017. Pemilihan siswa kelas X 1 SMA Islam 1 Surakarta dalam penelitian ini didasarkan pada pertimbangan bahwa subjek tersebut mempunyai permasalahan-permasalahan yang terlah teridentifikasi pada saat observasi awal. Objek penelitian ini adalah kualitas proses dan hasil belajar siswa. Kualitas proses belajar siswa dibatasi pada aktivitas belajar yang meliputi oral activities, visual activities, listening activities, dan writing activities. Sedangkan kualitas hasil belajar siswa yaitu prestasi belajar siswa meliputi aspek kognitif dan aspek afektif.

Data penelitian yang dikumpulkan meliputi data pra siklus dan data siklus I dan siklus II. Data pra penelitian melipui data kesulitan belajar siswa, data kondisi pembelajaran kimia, dan nilai ulangan harian kelas $X$ semester ganjil tahun pelajaran 2015/2016. Data pra penelitian digunakan sebagai pendukung pelaksanaan penelitian. Sedangkan data penelitian berupa data aktivitas belajar siswa dan prestasi belajar siswa yang meliputi aspek kognitif dan afektif siswa kelas X 1 SMA Islam 1 Surakarta tahun pelajaran 2016/2017 khususnya pada materi ikatan kimia.

Data yang dikumpulkan dalam penelitian ini meliputi informasi tentang keadaan siswa dilihat dari aspek kualitatif dan kuantitatif. Aspek kualitatif berupa data hasil observasi dan wawancara yang menggambarkan proses pembelajaran di kelas, aktivitas belajar siswa, dan kesulitan yang dihadapi guru baik dalam menghadapi siswa maupun cara mengajar di kelas. Aspek kuantitatif yang dimaksud adalah berupa data penilaian prestasi belajar siswa pada materi ikatan kimia yang meliputi aspek kognitif dan afektif baik siklus I maupun siklus II.

Teknik analisis data menggunakan analisis deskriptif kualitatif. Analisis data menggunakan triangulasi data yang terdiri dari tiga tahapan, yaitu reduksi data, pemaparan data, dan penarikan kesimpulan [8].

\section{HASIL DAN PEMBAHASAN}

Kondisi awal pembelajaran kimia diketahui berdasarkan hasil observasi dan wawancara terhadap guru mata pelajaran kimia kelas $\mathrm{X}$. Pada kondisi awal, siswa mengalami kesulitan dalam mempelajari materi ikatan kimia yang berisi konsep dan penggabungan atom. Aktivitas belajar siswa tergolong rendah. Penelitian dilaksanakan dalam 2 siklus.

\section{Siklus I \\ Perencanaan}

Pada tahap perencanaan, peneliti dan guru mata pelajaran kimia mempersiapkan beberapa perangkat penelitian, berupa silabus, Rencana Pelaksanaan Pembelajaran (RPP), dan instrumen penilaian prestasi belajar. Siklus I terdiri dari 4 kali pertemuan untuk menyampaikan materi dan 1 kali untuk evaluasi.

\section{Pelaksanaan Tindakan}

Siklus I dilaksanakan pada tanggal 1 September hingga 15 September 2016. Pada tahap awal pembelajaran, siswa dibagi ke dalam kelompok heterogen. Guru menyampaikan materi 
secara jelas, rinci, langkah demi langkah disertai contoh-contoh soal. Beberapa penjelasan dari guru dibantu dengan media aplikasi hyperchem, kemudian dilanjutkan siswa diskusi secara berkelompok untuk menyelesaikan soal diskusi sesuai dengan materi yang telah disampaikan guru. Guru memandu siswa untuk menyelesaikan latihanlatihan soal dan memberikan langkahlangkah penyelesaiannya secara rinci ke beberapa kelompok yang mengalami kesulitan. Beberapa perwakilan siswa menuliskan penyelesaiannya di papan tulis dan dibahas bersama.

Selama

pelaksanaan

pembelajaran siswa tidak kesulitan dengan model pembelajaran yang digunakan karena model yang digunakan sederhana. Pada akhir pembelajaran, siswa diberikan beberapa pertanyaan dan kesempatan bertanya terkait materi yang disampaikan. Pemahaman siswa terhadap materi yang telah disampaikan dapat diketahui melalui hasil seatwork yang diberikan setiap akhir pertemuan.

\section{Pengamatan}

Pengamatan terhadap aktivitas siswa dilakukan selama proses pembelajaran berlangsung. Data yang diperoleh dalam penelitian ini adalah data aktivitas belajar siswa dan prestasi belajar siswa yang meliputi aspek kognitif dan afektif.

Aspek yang dinilai dari aktivitas belajar siswa, antara lain oral activities, visual activities, listening activities, dan writing activities. Data aktivitas belajar yang diperoleh meliputi data pra tindakan dan data tindakan siklus I, yang terdiri dari observasi, angket penilaian diri, dan wawancara. Ringkasan hasil pengambilan data aktivitas belajar siswa disajikan pada Tabel 1

Tabel 1. Hasil Aktivitas Belajar Siswa

\begin{tabular}{lrr}
\hline \multirow{2}{*}{ Kriteria } & \multicolumn{2}{c}{ Ketercapaian (\%) } \\
\cline { 2 - 3 } & $\begin{array}{c}\text { Pra } \\
\text { tindakan }\end{array}$ & Siklus I \\
\hline Sangat Tinggi & 7,41 & 18,52 \\
Tinggi & 66,67 & 74,07 \\
Rendah & 25,93 & 7,41 \\
Sangat Rendah & 0,00 & 0,00 \\
\hline
\end{tabular}

Target aktivitas belajar siswa adalah $65 \%$ memiliki kriteria tinggi. Hasil pra tindakan menunjukkan bahwa $66,67 \%$ siswa memiliki aktivitas belajar yang tinggi, namun terdapat 25,93\% siswa dengan kriteria yang rendah sehingga perlu dilakukan penilaian pada siklus I. Hasil siklus I menunjukkan bahwa $74,07 \%$ siswa telah memiliki aktivitas belajar dengan kriteria tinggi. Target untuk aktivitas belajar telah tercapai sehingga tidak dilakukan penilaian pada siklus II Pelaksanaan diskusi dalam penerapan model pembelajaran langsung memberikan kesempatan kepada siswa untuk bertanya kepada teman sekelompok dan juga kepada guru tentang soal-soal yang belum dimengerti oleh siswa sehingga aktivitas belajar siswa semakin meningkat.

Data prestasi belajar aspek kognitif siswa diambil pada akhir siklus I berupa tes obyektif. Ringkasan hasil pengambilan data prestasi belajar aspek kognitif siswa pada siklus I disajikan pada Tabel 2.

Tabel 2. Hasil Belajar Aspek Kognitif Siswa Pasca Siklus I

\begin{tabular}{lc}
\hline \multicolumn{1}{c}{ Kriteria } & Ketercapaian (\%) \\
\hline Tuntas & 14,82 \\
Belum Tuntas & 85,18 \\
\hline
\end{tabular}

Target untuk prestasi belajar aspek kognitif yaitu $70 \%$ siswa mencapai ketuntasan dengan KKM 70. Hasil dari siklus I menunjukkan masih diperlukan perbaikan terhadap pembelajaran yang dilaksanakan agar ketuntasan belajar siswa meningkat. Oleh karena itu, dilakukan serangkaian perencanaan untuk pelaksanaan siklus II.

Data prestasi belajar aspek afektif didapatkan berdasarkan observasi selama pembelajaran, angket penilaian diri siswa, dan wawancara guru mata pelajaran kimia. Aspek yang dinilai pada prestasi belajar afektif siswa, antara lain sikap, minat, konsep diri, nilai, dan moral. Ringkasan hasil pengambilan data prestasi belajar aspek afektif siswa disajikan pada Tabel 3. 
Tabel 3. Ringkasan Hasil Belajar Aspek Afektif Siswa

\begin{tabular}{lcc}
\hline \multirow{2}{*}{ Kriteria } & \multicolumn{2}{c}{ Ketercapaian (\%) } \\
\cline { 2 - 3 } & $\begin{array}{c}\text { Pra } \\
\text { tindakan }\end{array}$ & Siklus I \\
\hline Sangat Baik & 3,70 & 11,11 \\
Baik & 70,37 & 77,78 \\
Kurang & 25,93 & 11,11 \\
Sangat Kurang & 0,00 & 0,00 \\
\hline
\end{tabular}

Target untuk prestasi belajar aspek afektif adalah $65 \%$ siswa memiliki kriteria baik. Hasil pra tindakan menunjukkan $70,37 \%$ siswa memiliki kriteria baik, namun terdapat 25,93\% siswa dengan kriteria kurang sehingga perlu dilakukan penilaian pada siklus I. Hasil siklus I menunjukkan bahwa $77,78 \%$ siswa telah memiliki prestasi belajar aspek afektif dengan kriteria baik. Target untuk prestasi belajar aspek afektif telah tercapai sehingga tidak dilakukan penilaian pada siklus II.

\section{Refleksi}

Berdasarkan hasil evaluasi pada siklus I, perlu dilakukan tindakan untuk memperbaiki proses pembelajaran materi Ikatan Kimia dengan model pembelajaran langsung. Pelaksanaan tindakan siklus II bertujuan untuk meningkatkan prestasi belajar siswa pada aspek kognitif karena masih ada beberapa indikator yang memiliki persentase di bawah target. Salah satu indikator soal dengan persentase ketuntasan paling rendah pada siklus I adalah menentukan unsur-unsur yang dapat berpasangan membentuk ikatan kovalen jika diketahui konfigurasi elektronnya dan menentukan senyawasenyawa yang dapat berikatan. Rendahnya persentase ketuntasan siswa diakibatkan oleh siswa belum sepenuhnya paham dengan konsep ikatan kovalen, ikatan hidrogen dan siswa masih bingung merangkai ikatan hidrogen apabila senyawanya berbeda dengan yang dicontohkan saat pembelajaran serta siswa menjadi bingung saat unsurnya dimisalkan seperti unsur $P, Q, R$, S dan lainnya.

Pelaksanaan siklus II berbeda dengan siklus I, dimana kelompok diskusi dibagi berdasarkan hasil evaluasi aspek kognitif siklus I dengan anggota masing-masing kelompok lebih sedikit daripada siklus I agar diskusi lebih efektif. Perbedaan lainnya adalah, soal yang digunakan untuk evaluasi aspek kognitif siklus II merupakan soal yang telah dibuat dan dimodifikasi oleh penulis sedekimian rupa pada indikator yang belum tercapai saja.

\section{Siklus II \\ Perencanaan}

Pelaksanaan siklus II direncanakan berdasarkan hasil refleksi pelaksanaan siklus I. Berdasarkan hasil siklus I, diketahui bahwa hasil aktivitas belajar siswa dan prestasi belajar aspek afektif telah mencapai target dan mengalami peningkatan dari data pratindakan. Pada siklus II hanya dilakukan penilaian terhadap prestasi belajar siswa aspek kognitif terhadap indikator kompetensi yang belum tuntas pada siklus I.

Siklus II pada penelitian ini terdiri dari 1 kali pertemuan untuk pendalaman materi dan 1 kali untuk evaluasi. Materi yang disampaikan pada siklus II merupakan materi pada indikator kompetensi yang belum tuntas pada evaluasi siklus I.

\section{Pelaksanaan Tindakan}

Pembelajaran dimulai dengan guru menjelaskan secara jelas, rinci, langkah demi langkah disertai contohcontoh soal materi yang belum tuntas pada evaluasi siklus I dan dilanjutkan dengan pengerjaan contoh soal untuk memperdalam pemahaman siswa terkait materi yang dibahas.

Pada pelaksanaan siklus II, kelompok diskusi siswa diatur kembali menjadi kelompok lebih kecil berdasarkan hasil siklus I. Kelompok diskusi yang lebih kecil membuat diskusi yang dilaksanakan lebih efektif. Siswa yang sebelumnya tidak mau bertanya menjadi bertanya. Guru memandu siswa untuk menyelesaikan latihan-latihan soal dan memberikan langkah-langkah penyelesaiannya secara rinci ke beberapa kelompok yang mengalami kesulitan. Beberapa perwakilan siswa 
menuliskan penyelesaiannya di papan tulis dan dibahas bersama.

Siswa diberi kesempatan untuk bertanya mengenai soal pada evaluasi siklus I yang dirasa sulit. Jika dibandingkan dengan siklus I siswa lebih sering bertanya kepada guru apabila belum paham. Pada akhir pembelajaran diberikan seatwork untuk mengetahui pemahaman siswa.

\section{Pengamatan}

Pengamatan pada siklus II terpusat pada aspek kognitif siswa. Penilaian terhadap aspek kognitif siswa dilaksanakan pada akhir siklus berupa soal pilihan ganda yang terdiri dari 20 butir soal berdasarkan pada indikator yang belum tercapai di siklus I dengan modifikasi soal dari siklus I.

Ringkasan hasil pengambilan data prestasi belajar aspek kognitif siswa pada siklus II disajikan pada Tabel 4 .

Tabel 4. Hasil Belajar Aspek Kognitif Siswa Pasca Siklus II

\begin{tabular}{lc}
\hline \multicolumn{1}{c}{ Kriteria } & Ketercapaian (\%) \\
\hline Tuntas & 77,78 \\
Belum Tuntas & 22,22 \\
\hline
\end{tabular}

Hasil aspek kognif siswa pada siklus II menunjukan peningkatan persentase ketuntasan siswa sebesar $62,96 \%$ dari $14,82 \%$ pada siklus I meningkat menjadi $77,78 \%$ pada siklus II. Peningkatan persentase pada tiap indikator kompetensi menunjukkan bahwa pelaksanaan tindakan siklus II dapat memperbaiki masalah yang muncul pada siklus I. Kelompok diskusi siklus II dibagi secara heterogen berdasarkan hasil tes aspek kognitif siklus I. Siswa menjadi lebih berani bertanya terkait soal-soal yang dirasa belum paham.

\section{Refleksi}

Pada pelaksanaan siklus II, guru menekankan pada materi yang belum dikuasai siswa. Kelompok diatur sedemikian rupa berdasarkan hasil evaluasi siklus I sehingga diskusi berjalan lebih maksimal dan menjadikan lebih banyak siswa yang berani bertanya sehingga dapat meningkatkan aktivitas belajar siswa.

Hasil yang diperoleh berdasarkan evaluasi pada akhir siklus II menunjukkan bahwa penerapan model pembelajaran langsung disertai diskusi mampu meningkatkan prestasi belajar aspek kognitif siswa, dari 14,82\% siswa tuntas pada siklus I naik menjadi $77,78 \%$ pada siklus II.

\section{Perbandingan antar Siklus}

Perbandingan antar siklus dilakukan untuk mengetahui perbedaan hasil yang didapatkan pada pratindakan, siklus I, dan siklus II.

Pada pembelajaran langsung disertai diskusi terjadi peningkatan hasil, baik dari pra tindakan, siklus I, ataupun siklus II. Perbandingan hasil dapat dilihat pada Gambar 1.

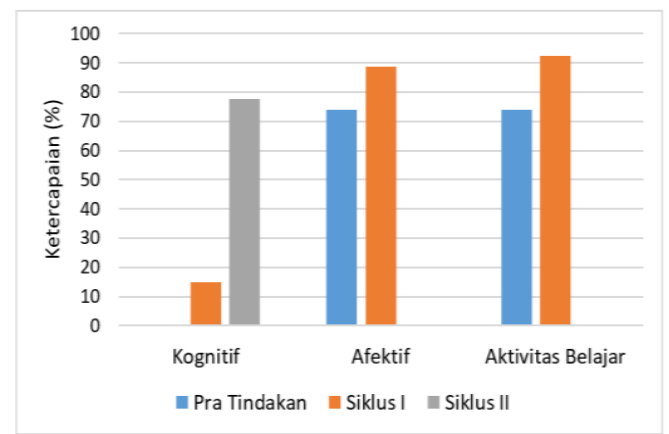

Gambar 1. Histogram pencapaian prestasi belajar aspek kognitif, aspek afektif, dan aktivitas belajar

Berdasarkan hasil yang telah dipaparkan, secara keseluruhan dapat dilihat bahwa penelitian model pembelajaran langsung (direct instruction) disertai diskusi dan media hyperchem pada materi ikatan kimia kelas X 1 SMA Islam 1 Surakarta tahun pelajaran 2016/2017 mampu meningkatkan aktivitas belajar dan prestasi belajar berupa aspek kognitif dan aspek afektif.

\section{KESIMPULAN}

Berdasarkan hasil penelitian dapat disimpulkan bahwa penerapan model pembelajaran langsung (direct instruction) disertai diskusi dan media hyperchem dapat meningkatkan 
aktivitas belajar dan prestasi belajar siswa pada materi ikatan kimia di kelas $X \quad 1$ SMA Islam 1 Surakarta tahun pelajaran 2016/2017. Aktivitas belajar siswa mencapai $92,59 \%$ pada siklus I dan tidak dilanjutkan pada siklus II. Aspek kognitif siswa pada siklus I sebesar $14,82 \%$ meningkat menjadi $77,78 \%$ pada siklus II. Aspek afektif mencapai $88,88 \%$ pada siklus I dan tidak dilanjutkan pada siklus II.

\section{UCAPAN TERIMA KASIH}

Peneliti mengucapkan terimakasih dan penghargaan yang tulus kepada Bapak Drs. Sudadi Wahyono selaku Kepala SMA Islam 1 Surakarta yang telah memberikan izin untuk mengadakan penelitian di lingkungan SMA Islam 1 Surakarta. Kepada Ibu Dwidjajanti, S.Pd., selaku guru mata pelajaran kimia SMA Islam 1 Surakarta yang telah mengizinkan peneliti untuk menggunakan kelasnya dalam penelitian ini.

\section{DAFTAR RUJUKAN}

[1] Hamalik, O. (2011). Dasar-dasar Pengembangan Kurikulum. Bandung: PT Remaja Rosdakarya.

[2] Mulyasa, E. (2011). Kurikulum Tingkat Satuan Pendidikan. Bandung: Remaja Rosdakarya.

[3] Arifin, M. (1995). Pengembangan Program Pengajaran Bidang Studi Kimia. Surabaya: Airlangga Press.

[4] Indrawati. (2005). Model Pembelajaran Langsung. Bandung: Departemen Pendidikan Nasional Ditjen Pendidikan Dasar dan Menengah.

[5] Setiawan, W., Fitrajaya, E., \& Mardiyanti, T. (2010). Jurnal Pendidikan Teknologi Informasi dan Komunikasi, 3 (1), 7-10.

[6] Yunitasari, W., Susilowati, E., \& Nurhayati, N.D. (2013). Jurnal Pendidikan Kimia, 2 (3), 182-190.

[7] Chonstantika, A. L., Haryono, \& Yamtinah, S. (2013). Jurnal Pendidikan Kimia, 2 (3), 25-33.

[8] Miles, M. B. \& Huberman, A. M. (1995). Analisis Data Kualitatif. Jakarta: UI-Press. 